\title{
The moderating effects of institutional qualities and energy use on the economic output
}

\author{
Abdulrasheed Zakari* \\ ${ }^{1}$ Center for Energy and Environmental Policy Research \\ Beijing Institute of Technology, Beijing China \\ ${ }^{2}$ Alma Mater Europaea Maribor, Slovenia \\ el_rasheed81@yahoo.com / abdulrasheed.zakari@almamater.si
}

\author{
$\underline{\text { Jurij Toplak }}$ \\ ${ }^{1}$ University of Maribor, Slovenia \\ ${ }^{2}$ Alma Mater Europaea ECM, Maribor, Slovenia \\ jurij.toplak@almamater.si
}

Corresponding Author*

\section{Abstract}

Energy and institutional quality are two factors that determine economic output, but these two factors are often neglected in the search for economic output. Therefore, this study examines the relative importance of energy use and its interaction with institutional quality for economic output. We employ a robust econometric estimation technique on a panel sample of 21 African countries between 2002-2019. Our results show that energy use is significant and negatively related to economic output while moderating terms of institutional quality are significantly associated with economic output, but the direction of the association depends on the specific quality. We find the moderating term control of corruption and government effectiveness to be negative and significantly associated with economic output, whilst political stability, regulatory quality, rule of laws, voice, and accountability positively impact. Our results imply that improved economic output is possible when there are specific institutional strategies. 
Keywords; Economic output; Energy use; Institutional quality; cultural diversity; FMOLS

\section{Introduction}

The energy industry has received attention from public and private individuals in the African region, which were pushed by many factors; (1). The growing population with a lack of access to electricity has reached over 600 million, and 900 million people lack access to clean cooking facilities (International Energy Agency, 2018); (2). Frequent fluctuation in oil prices and energy security; (3). Other concerns such as climate change and fossil energy consumption; (4). Economic losses, with the region command low economic growth estimated to be $2.8 \%$ in 2018 , far lower than South Asian of 7.1\% (International Monetary Fund, 2018). This makes the energy valued by public and private individuals. However, energy may be both advantages and disadvantages. Does the use of energy bring too high economic costs? Would the use of energy hinder economic output? What is the mechanism behind it?

The leakage between energy use and economic growth has been widely examined. First, some researchers have conclude that energy consumption could be pivotal for economic growth and output (Akinlo, 2008; Dogan et al., 2020; Wang and Wang, 2020; Chen et al., 2020). On the other hand, other scholars (Liu et al., 2020; Shahbaz et al., 2020) pointed out a negative relationship between energy use and economic growth or outputs. Therefore, this paper aims at providing a more convincing argument. There are two main highlights and the contribution in this paper. First, we establish a model to examine the role of energy use on economic outputs. Second, in this paper, we moderate the six institutional quality over energy use to find the relationship between energy use and economic output in an institutional quality environment.

Our results are as follows. First, we find that energy use is negative and significantly associated with economic output, suggesting that energy use is detrimental to economic output. Second, we 
find that all the six institutional quality as moderating terms are significant and associated with economic output. However, the direction of the association is not the same for all institutional quality. Third, we find the moderating term control of corruption and government effectiveness are negatively related to economic output, suggesting that countries with these two institutional qualities as dominating quality are more likely to be slow-down economic output. Fourth, the moderating terms political stability, regulatory quality, rule of laws, and voice and accountability are positive drivers of economic outputs, affirming that political stability is needed to encourage investors to invest in an economy. Our results are robust to alternative econometric identification strategies.

This study fits within a larger literature on the determinants of economic growth or output, but it provides a distinctively different perspective on how non-economic factors such as institutional quality influence economic output. Although there is some existing literature on the relationship between energy use and economic growth or outputs (Akinlo, 2008; Dogan et al., 2020; Wang and Wang, 2020; Chen et al., 2020), their study focuses on the economic variables, neglecting the impact in which non-economic variables such as institutional quality. If institutional quality is ignored, the true impact of energy use will not reflect on the economic output or growth because countries' characteristics differ. More importantly, institutional quality enhances a country's ability to adopt new technologies invented elsewhere, which may help upgrade development (Nawaz et al., 2014).

Our study provides more direct evidence on how institutional quality affects the economic output by focusing on the impact within the institutional quality point of view. The findings on the cultural diversity that has not been analyzed in prior studies before provide new evidence on how numerous social divisions affect economic growth or output. As evident in the results, cultural diversity 
factors are positively and negatively associated with economic output depending on the country's institutional quality, implying that more diversity brings new perspectives on making our world a better place.

Our paper is timely in understanding whether a country is likely to achieve goals 8 of Sustainable Development Goals by the 2030 deadline given their institutional quality and energy. It provides empirical evidence to Parks et al. (2017) that the lack of attention to the weak institution by developing countries has impeded growth. That is, energy and institutional quality are inevitable that shape institutions towards economic growth or output. The findings informed policymakers that different forms of energy use and institutional quality affect economic output differently. Hence it is more prudent to adopt specific strategies for different regions in the country than the usual wholesale strategy, which is mostly institutionally insensitive.

The remainder of the paper is as follows. The literature review is presented in Section 2. The research method, including theoretical background, variable measurement, and econometric modeling, is presented in Section 3. The results of results and discussion are present in Section 4. The policy implications of the estimations are presented in Section 5. The paper is concluded in Section 6. 


\section{Literature review}

As a country, we all want to prosper our economy, and determination to achieve a prosperous economy is primarily driven by the country's institutional qualities. Therefore the quest to correct our negative economic activities through energy is significantly influenced by institutional settings (Nguyen et al., 2018). Nawaz et al. (2014) argue that economic growth can be achieved if the institutional settings are functioning well. Whether it is petty or large, any institutional environment towards energy use is significantly shaped by the institutions' quality.

\subsection{Energy use and economic output}

In a study for 11 Sub Saharan African countries, Akinlo (2008) argues that energy consumption is an important factor determining long-run economic growth, particularly to countries like Ghana, Kenya, Senegal, and Sudan. To be specific, renewable energy use is more effective in achieving economic growth than non-renewable energy (Dogan et al., 2020). On the other hands, the impacts changes in some circumstances, when the per capita income cross above the threshold, it is expected that more people will embrace the use of the renewable energy source and that enhance economic growth (Wang and Wang, 2020). Therefore, renewable energy consumption matters most in the developing countries, and to attain the level of economic growth depends on the amount of renewable energy consumed. Consumption above a certain threshold will enhance economic growth (Chen et al., 2020).

Energy is undoubtedly an important factor in economic decision-making; however, the impact of energy on the economy is mostly reducing pollutions where economic development continues to deteriorate (Liu et al., 2020). In effect, renewable energy consumption is associated with low 
carbon emission, but its usage is insignificant to economic prosperity. That's why countries like Canada, France, Spain, India, Turkey, the United Kingdom, and Norway continue to depicted negative economic growth. This is expected since these countries use an insignificant renewable energy level in running economic activities (Shahbaz et al., 2020).

\subsection{The Institutional quality and economic output}

Institutional quality is a broad concept that captures law, individual rights, and high-quality government regulation and services (Acemoglu et al., 2005). As such, World Bank (2020) has consolidated these different institutional quality aspects into six, which have since become the major measure of institutional quality in the literature. These institutional qualities are control of corruption, government effectiveness, political stability, regulatory quality, the rule of law, and voice and accountability. Following prior studies (Cieslik and Goczek, 2017; Guo and He, 2020; Nirola and Sahu, 2019), we employ six institutional quality reported by the World Bank.

\section{Control of corruption}

The corruption halts economic growth through the impact on investment. In a free economy system, international investment is likely to be diverted. In an attempt to avert tax on entrepreneurship and productive, international investors divert their investments, therefore decreasing the return on investment and increasing variance, which discourages investment activities (Cieslik and Goczek, 2017). According to Alfada (2019), the effect of corruption on economic growth depends on the extent of corruption. Corruption below threshold does not harm the economic growth, while corruption above certain thresholds hampers economic growth.

The country setting also factors; the developing countries, for instance, are expected to depict negative economic growth because of their poor institutional quality and give room for corruption 
to operate. The positive relationship between control of corruption and economic growth implies that strong institutional quality, which encourages investment and economic development (Qureshi et al., 2020). Similarly, an autocracy system is deemed to decrease economic growth because it translates to growth through a decrease in foreign direct investment and increases inflation rates (Grundler and Potrafke, 2019).

\section{Government effectiveness}

How effective the government implements its policies are likely to enhance economic growth. Specifically, if handled effectively, government spending and expenditure will positively affect economic growth (Divino et al., 2020). Therefore, states with better institutional systems are bound to have a lower negative impact on growth than the weak institutional system of high impact on growth. More so, by effectively reduce spending on the non-development project tents to improve economic growth (Nirola and Sahu, 2019). This means that the marginal benefit for economic growth that could have been engineer by private and public spending will be halt until there is an improvement in the quality of governance quality.

Fiscal transparency often drives effective governance by promoting better fiscal policy (Montes et at., 2019). Nedic et al. (2020) argue that institutions that embrace government effectiveness and regulatory quality are likely to earn the greatest economic growth. That to say, better governance tends to promote productivity and income growth when government size (Kim et al., 2018). However, the effectiveness of governance lies in the government setting. In a free system, governance tends to work slowly than when the government holds the economy's ultimate charge (Huang and Ho, 2017). It simply mean that the government should take charge of the economy, and with that, governance can be enforced effectively to accelerate economic growth. 


\section{Political Stability}

Political may likely be a factor deriving economic growth; since political leaders are more likely contest and are selected in political office in a politically stable environment and increase the likelihood of economic growth (Yu et al., 2020). Having this, political stability is pivotal for economic growth irrespective of the country settings (Uddin et al., 2017). Unlike the political instability, which is associated with the high uncertainty that investors may face concerning the security of property rights. Hence, a politically stable environment becomes necessary to persuade investors to invest since the property right is assured (Radu, 2015).

The international tourist invigorates economic growth; however, the political system's instability impedes the tourist from coming to a country, as such economic growth is affected negatively (Tang and Abosedra, 2014). Particularly, terrorism-related instability has the greatest impact since it collapses market activities. This raises the market uncertainty and portrays a lousy signal to both local and foreign investors to hold their investments because of the risk of investing in such a volatile environment. Therefore, the economic activities crumble and create high inflation, unemployment, and aggravate poverty (Tabassam et at., 2016).

\section{Regulatory quality}

Government regulation matters a lot in the economy, but ineffective government regulations could deter a business start. Hence, low productivities and inadequate economic growth (Polemis and Stengos, 2020). Enhancing institutional infrastructure, particularly regulatory quality, may encourage the local markets and financial development. As expected, the domestic market and financial development will enable improvement in economic growth in the long-run (Nasreen et 
al., 2020). The effect may not be linear, leading to the diminishing return on economic growth. Countries with higher regulatory quality benefited less from economic growth than the countries with less regulatory quality improvement, which seems to be the highest benefit of economic growth (Silberberg and Koniger, 2016).

\section{Rule of laws}

The government's inability to lift to its expectation by providing law and order is most like the brain behind the barrier to economic growth. It will be wrong to believe that corruption is the fundamental barrier to economic growth in widespread violence. But rather is the failure of the states to take it the responsibility of restoration of order. It became paramount to restore order in the economy to have well economic growth. The rule of law will make a promising increment on the economic growth in more advanced industrial economies than developing economies' benefits (Haggard and Tiede, 2011).

Sometimes countries' characteristic matters in achieving economic growth. The rule of law significantly improves growth, but countries who have adopted a democratic government system benefited the most from economic growth (Butkiewicz and Yanikkaya, 2006). Mauro et al. (2018) argue that government to whom want to achieve decentralized policy to promote economic growth most carefully chose the rule of laws. That is, the rule of laws matter a lot in making a decision about economic growth. The rule of law can also indirectly influence economic growth by reducing carbon emissions and improving environmental quality, which restores investors' confidence to invest in considering the health condition (Muhammad and Long, 2021). 


\section{Voice and Accountability}

The role of government in a democratic setting is to be accountable to its citizens. More importantly, being accountable in rendering spending, particularly on the capital project, has many effects than spending on current projects-States tend to benefit from an increase in revenues (Morozumi and Veiga, 2016). More so, as countries witness a fall in corruption level or a rise in the quality of bureaucracy, public spending became effective, particularly when on health (Rajkumar and Swaroop, 2008).

Overall, previous literature has harnessed the opportunity to assess energy use's role in the economic output (Akinlo, 2008; Dogan et al., 2020; Wang and Wang, 2020; Chen et al., 2020). However, these studies focus on the economic variables, neglecting the impact of non-economic variables such as institutional quality. If institutional quality is neglected, the true impact of energy use will not reflect on the economic output or growth because countries' characteristics differ. Given this fact, we would examine the role of energy use on economic output by moderating it with the six institutional quality.

\section{Empirical approach and data}

\subsection{Theoretical background}

It is important to highlight the modality behind our selected variable and the built econometric equations. We relied on the previous literature to build in the econometric equations and select variables. Following the research note by Paramti et al. (2017), where they investigate the role of renewable energy on economic outputs and the environment. In their study, they firmly maintain proxy for economic output as the measure of GDP (constant 2010 US\$). Likewise, Jing et al. (2016), Gbatu et al. (2019), and Bruns et al. (2014) whose examine the relationship between energy 
consumption and economic outputs. Gross domestic product here explain in monetary term the market value of all the finished goods and services produced within a country in a specific period of time (Paramati et al., 2017)

For the control variables, we include capital formations measured by the gross fixed capital formation to control for the investment. This is consistent with Ongo and Vukenkeng (2014) studies and Ugochukwu and Chinyere (2013). Lechman and Kaur (2015) argue that labor force participation plays a significant role in influence economic growth. Hence, we control for the impact of the labor force on economic outputs. Also, Caliskan (2015) argued that new technologies open a door for the production of cheaper goods and services. Therefore, we employed technologies to account for the effect of innovation on the economic outputs. These links among the variables are further explained in Fig 1.

\subsection{Model specification}

Following Adedoyin and Zakari (2020); Li et al. (2020), and Ouedraogo (2012), we adopt linear relation between economic growth and energy use with capital formation, labor force, and technology as control variables:

$$
E O_{i t}=\beta_{i}+\beta_{t}+\beta_{1} E U_{i t}+\beta_{2} C F_{i t}+\beta_{3} L F_{i t}+\beta_{4} T E C_{i t}+\varepsilon_{i t}
$$

Where subscripts i and t refer to country and year respectively, EO refers to the economic output and is measure by GDP (constant 2010 US\$), EU is energy use represent the energy consumption in a kilogram of oil equivalent per capita, CF refers to the fixed capital formation (constant 2010 US\$), LF represents the labor force. TEC mean technology has been proxied by the patent application. Country-fixed effects $\left(\beta_{i}\right)$ and time-fixed-effects $\left(\beta_{t}\right)$ are included to control for the 
unobserved country and time-variant common shocks, respectively, and $\varepsilon_{i t}$ is the error term for country $\mathrm{i}$ in year $\mathrm{t}$.

Note that eq., 1 is postulate to examine the hypothesis that states that energy consumed can be relevant in explaining the economic output across countries. Further, the analysis extends the eq., 1 by moderating institutional qualities (such as control of corruption, government effectiveness, political stability, regulatory quality, rule of laws, and voice and accountability). Namely,

$$
\begin{gathered}
E O_{i t}=\beta_{i}+\beta_{t}+\beta_{1}(E U * \text { Institutional qualities })_{i t}+\beta_{2} C F_{i t}+\beta_{3} L F_{i t}+\beta_{4} T E C_{i t} \\
+\varepsilon_{i t}
\end{gathered}
$$

Where we moderate energy use with institutional qualities (such as control of corruption, government effectiveness, political stability, regulatory quality, rule of laws and voice and accountability) for the country $i$ and $t$ for time-variant. Eq. 2 is intend to examine the role of energy use in an excellent institution and its economic output or growth impact. To justify our study, we further include more control variables - cultural diversity into the eq., 3 as follow:

$$
\begin{gathered}
E O_{i t}=\beta_{i}+\beta_{t}+\beta_{1}(E U * \text { Institutional quality })_{i t}+\beta_{2} C F_{i t}+\beta_{3} L F_{i t}+\beta_{4} T E C_{i t} \\
+\beta_{5}(\text { Cultural dimension })_{i t}+\varepsilon_{i t}
\end{gathered}
$$

Where an array of cultural dimensions that includes the indexes on power distance (PDI), individualism (IND), uncertainty avoidance (UAI), masculinity (MAS), long-term orientation (LTO), and indulgence versus restraint (IVR) for country i. These cultural dimensions vary across countries, but they are invariant across time for a given country. The inclusion of cultural dimension variables to justify whether the energy use will react different or not. 


\subsection{Estimation Method}

\subsubsection{Unit-root test}

Before estimating the variables, we perform (2002) -LLC and ( Harris-Tzavalis, 1999) - HTT unit root test to ascertain the stationary series. We chose the two approaches because of their reliability. We have the general form of the model considered in this paper can be written as follows:

$$
\begin{array}{ccc}
y_{i t}=\alpha_{i}+\delta t+\mu_{i t} \mathrm{t}=1, . . \mathrm{T} ; \mathrm{i}=1, \ldots \mathrm{N} & \\
u_{i t}=\rho u_{i, t-1}+\varepsilon_{i t} & \varepsilon_{i t} \sim\left\{0, \sigma_{t}^{2} \sigma_{\varepsilon}^{2}(i)\right\} & / \rho /<1 \\
y_{i t}=(1-\rho) \alpha_{i}+(1-\rho) \delta t+p y_{i, t-1}+\varepsilon_{i t} & \varepsilon_{i t} \sim\left\{0, \sigma_{t}^{2} \sigma_{\varepsilon}^{2}(i)\right\} & \rho=1
\end{array}
$$

\subsubsection{Co-integration test}

Previous studies have applied a series of panel co-integration techniques such as Pedron's (EngleGranger-based) technique and Fisher's (combined Johansen) technique. However, those techniques were proven to pose some limitations; hence we use the Kao test of co-integration. Kao test con-integration is chosen because it is a co-integration technique that calculates and pools all the residuals of all the cross-sections in the panel data set and assumes that each co-integrating vector in each cross-section is identical (Maddala and Wu, 1999). This study employs Kao’s (1999) panel co-integration test to confirm the long-run relationship among the selected variables:

$$
D F^{*}=\frac{t_{\rho}+\frac{\sqrt{6 N} \widehat{\sigma}_{v}}{2 \widehat{\sigma}_{0 v}}}{\sqrt{\frac{\widehat{\sigma}_{0 v}^{2}}{2 \widehat{\sigma}_{v}^{2}}+\frac{3 \widehat{\sigma}_{v}^{2}}{10 \widehat{\sigma}_{o v}^{2}}}}
$$

Where $t_{\rho}$ is parametric t-statistic, $\hat{\sigma}_{v}^{2}$ and $\hat{\sigma}_{0 v}^{2}$ are stable estimates of $\sigma_{v}^{2}$ and $\sigma_{0 v}^{2}, \hat{\sigma}_{v}^{2}=\hat{\sigma}_{v}^{2}-$ $\hat{\sigma}_{v \varepsilon}^{2} \sigma_{\varepsilon}^{-2}$ demonstrate short-run variance estimates, and $\hat{\sigma}_{o v}^{2}=\hat{\sigma}_{o v}^{2}-\hat{\sigma}_{o v \varepsilon}^{2} \sigma_{0 \varepsilon}^{-2}$ indicates long-run variance estimates. 


\subsubsection{Full modified ordinary least square (FMOLS)}

Following our co-integration test, we employ a panel FMOLS approach to examine the long-run relationship between economic output and energy use. The choice of this model over other econometric models because of its power to overcome inference problems (Himansu et al., 2007). The regression model proposed by Padroni (2000) is shown in equation (5):

$Y_{i t}=\alpha_{i}+\beta x_{i t}+\mu_{i t}$

Where $x_{i t}=x_{i t}-1+\varepsilon_{i t}, \mathrm{i}=1 \ldots \mathrm{N}$, and $\mathrm{t}=1 \ldots \mathrm{T}$, for which we model the vector error process.

\subsection{Data description}

Our research's main objective is to determine the impact of energy use on the economic output of 21 African countries (See Appendix). We also aim to identify the moderating effects of institutional quality. We collected the balanced panel data from 2002 to 2019 . Table 1 provides details about the variables we incorporated into this research.

[Insert Table 1 here]

\section{Results and discussion}

We present the descriptive statistics of the variables in Tables 2. The mean energy use is 980.239, with a higher standard error deviation (744.63), indicating large variations among the sample countries. The average economic output $(7.580 \mathrm{e}+10)$ is higher than the capital formation $(1.780 \mathrm{e}+10)$, meaning that most countries' economic output increases over time. While the labor force (12400000), higher than the technologies (162.425), shows that most countries embrace human-being as labor force than they use technologies in producing goods and services. Fig 2. 
describes the graphic interaction of the selected variable, and the results show that Egypt, Nigeria, and South Africa top the list of the countries with the highest growing economic outputs.

\section{[Insert Table 2]}

Before we proceed with the analysis, it's necessary to check our dataset's stationarity. We employed Levin-Lin-Chu (2002) and Harris-Tzavalis (1999) unit-root test, and the results are presented in Table 3. Both tests show that all the variables are not stationary at the level stage except for capital formation (CF) and technology (TECH). However, when the variables are taken at first-different, our results for both tests show that our dataset are all stationary. Therefore, we can now estimate for co-integration to ascertain the long-run equilibrium among the variables.

\section{[Insert Table 3]}

Table 4 presented the report of Kao's cointegration, and the results show for the five components, 4 component rejects the alternative hypothesis of no long-run relationships among the variables at $1 \%, 5 \%$, and $10 \%$, respectively while only one component accept the alternative hypothesis. Hence, we confirm that our variables have long-run positive associations and move together in the long run.

[Insert Table 4]

We used the FMOLS model for the long-run estimates, and the results are presented in Table 5. The results show that column 1 suggests that energy use $(-0.00380 * * *)$ is negative and significant at $1 \%$. The findings show that energy use is associated with a reduction in economic output. This is consistent with Shahbaz et al. (2020), who argue that energy consumption will not always determine economic growth. Economically, a $1 \%$ increase in energy use will lead to a drop in 
economic growth by $0.00380 \%$. This is consistent with the argument that developing countries like Africa heavily rely on non-renewable energy, which is often not available for consumption. Hence, it will slow down the production process, reflecting low output. Therefore, the continued use of non-renewable leads to environmental degradation and slows down the productions of goods and services.

In columns 2 and 3, we reported energy use *control of corruption and energy use* government effectiveness. The coefficient of energy use*control of corruption $\left(0.000590^{* * *}\right)$ and energy use* government effectiveness $(-0.000650 * * *)$ are negative and significant at $1 \%$, suggesting that control on corruption and government effectiveness plays a role in enabling the energy use to lead to a reduction in economic outputs. This is expected because, in most African countries, the producing sectors are left in the hand of private enterprises. Hence, institutionalizing the control of corruption and improving government effectiveness will not directly affect the producing sectors since they have little government engagement. Therefore, the impact of energy use in the midst of control of corruption and government effectiveness may not improve economic outputs.

However, column 4 and 5 reported the results the moderation with political stability and regulatory quality, and the coefficient of the energy use*political stability (0.000493***), and energy use*regulatory quality $(0.000128 * * *)$ are positive and significant at $1 \%$, suggesting that having stable political environment and functioning regulatory quality has helped the energy use to increase the economic outputs. Economically, a $1 \%$ increase in energy use in an environment where there is a politically stable and good regulatory quality will increase the economic outputs by $0.000493 \%$ and $0.000128 \%$, respectively. This is consistent with the argument that political stability and effective regulatory power create an effective business environment to prosper. Given 
political stability and functioning regulatory capacities, no doubt that it will encourage foreign investors to invest. Therefore, the more investment prospers in the country, the likelihood that such an economy will produce large capacity given the energy source level. This means that energy is judiciously used to produce goods and services in a politically stable and functioning regulatory environment than otherwise, leading to increased production capacity.

Further, the rule of law and voice and accountability are presented in columns 6 and 7. The results show that the coefficient of energy use*rule of law $(0.000924 * * *)$ and energy use ${ }^{*}$ voice and accountability $(0.000238 * * *)$ are positive and significant at $1 \%$, indicating an environment with the rule of laws and voice and accountability will enable energy use to increase the economic outputs. Allowing the rule of laws and lending the voiceless voice and accountability give business more confidence to prosper. Hence, energy use is expected to be judiciously used in the environment where the rule of laws and voice is given to ordinary people. Such an approach to energy use often translates to an improvement in productions and, consequently, increases production capacity.

Results on most of the control variables are consistent with standard assumptions. For example, the labor force is positive and significant in most cases, implying that the labor force is an important factor that plays a major role in achieving economic outputs. However, capita formation and technology are negative and significant, indicating that they impede economic outputs in African countries.

[Insert Table 5] 


\subsection{Robustness check}

For robustness purposes, we include cultural dimension indicators, such as power distance, individualism, masculinity, uncertainty avoidance, long-term orientation, and indulgence. Our results are presented in Table 6. Given these additional controls, the energy use coefficient, energy use*control of corruption, and energy use*government effectiveness remain negative. Equally important, the impact of energy use*political stability, energy use*regulatory quality, and energy use*voice and accountability on the economic outputs nexus are confirmed. Our previous results are largely unaffected by these alternative estimations. Our additional control variables of cultural dimensions are significant in most of the panel. In some panels, it shows a negative relationship with economic outputs, while some show positive relationships. Invariably, what it means is that the impact of the six cultural dimensions on economic outputs depends on the country's philosophy on institutional qualities.

\section{[Insert Table 6]}

\section{Policy implications}

Having confirmed the nexus between energy use and its impact on the economic outputs considering the institutional qualities. It becomes necessary to draw some imperative lesson from our finding and make decisions as follows: 
Our results show that energy use and it moderating factors such as control of corruption, and government effectiveness prove to hamper the economic outputs, that to say, it reduces the production of goods and service in the country. Obviously, African slow economic outputs are caused by energy use within weak institutions who only mindful of controlling corruption and government effectiveness. Controlling corruption and improving government effectiveness will not directly impact the institutions that control the economy's production capacity. Hence, the impact of the measures (corruption control and improve government effectiveness) will instead hamper the production process. Therefore, we suggest that African countries, in as much as they control corruption and improve government effectiveness, there should be an improvement in other institutional qualities that directly impact the production sector of the economy, particularly measure that renewable energy orientation can be cultivated.

We also find that energy in a political stable, highly regulatory, the rule of law, and voice and accountability are judiciously used, leading to high productivity. This is expected since African countries are highly regimental; hence the productive sectors are in the hands of private individuals called enterprise. For effective proactive sectors operation, government intervention became necessary to promulgate laws and its implementation to prevent the private enterprise from extorting the public for their private gains. Therefore, we suggest African countries to improve institutional quality such as political stability, regulatory quality, rule of laws, and voice and accountability. Improving these institutions' qualities will further enhance the judicious use of energy, likely to improve economic output.

Beyond institutional qualities, African countries should implement the UN treaties agreement on energy use, particularly renewable energy use. The government should encourage renewable 
energy by issuing grants and subsidies to investors in renewable energy. Doing this will make energy available and cheaper for the productive sector to use and produce goods and services in a short period leading to an improvement in the economic outputs.

\section{Conclusion}

Given the importance of the economic outputs in an economy. This research note supports economic prosperity theory by highlighting the benefits of energy use and the moderating effect of institutional qualities on African countries' economic outputs. We moderate the energy use with six institutional qualities indices as prescribed in the WDI (2020) and add the six cultural dimensions to check for robustness. We adopt the FMOLS for both baseline and robustness analyses.

Our results imply that energy use may not be an effective medium through which economic outputs can be promoted because of the lack of energy. We also find that our moderating results to be significant, and control of corruption and government effectiveness does not enable the judicious use of energy; hence it hampers the economic outputs. However, not all six institutional qualities have a similar effect. As evident in our findings, political stability, regulatory quality, the rule of law, and voice, and accountability positively affect economic outputs. Therefore, this result means that policymakers need to adopt different strategies that fit the country's dominating institutional qualities. That is, it is will be prudent to have one generic economic prosperity strategy for all countries.

\section{References}


Acemoglu, D., Johnson, S. and J. A. Robinson (2005), 'Institutions as a Fundamental Cause of Long-Run Growth,' in: Aghion, P. and S. N. Durlauf (eds.), Handbook of Economic Growth, Volume 1A, Elsevier B.V., 385-472.

Akinlo, A. E. (2008). Energy consumption and economic growth: Evidence from 11 Sub-Sahara African countries. Energy Economics, 30(5), 2391-2400.

Alfada, A. (2019). The destructive effect of corruption on economic growth in Indonesia: A threshold model. Heliyon, 5(10), e02649.

Bruns, S. B., Gross, C., \& Stern, D. I. (2014). Is there really Granger causality between energy use and output?. The Energy Journal, 35(4).

Buhari, D. Ğ. A., Lorente, D. B., \& Nasir, M. A. (2020). European commitment to COP21 and the role of energy consumption, FDI, trade and economic complexity in sustaining economic growth. Journal of Environmental Management, 273, 111146.

Butkiewicz, J. L., \& Yanikkaya, H. (2006). Institutional quality and economic growth: Maintenance of the rule of law or democratic institutions, or both?. Economic Modelling, 23(4), 648-661.

Çalişkan, H. K. (2015). Technological change and economic growth. Procedia-Soc. Behav. Sci, 195, 649-654.

Chen, C., Pinar, M., \& Stengos, T. (2020). Renewable energy consumption and economic growth nexus: Evidence from a threshold model. Energy Policy, 139, 111295.

Cieślik, A., \& Goczek, Ł. (2018). Control of corruption, international investment, and economic growth-Evidence from panel data. World Development, 103, 323-335. 
Divino, J. A., Maciel, D. T., \& Sosa, W. (2020). Government size, composition of public spending and economic growth in Brazil. Economic Modelling, 91, 155-166.

Gbatu, A. P., Wang, Z., Wesseh, P. K., \& Sesay, V. A. (2019). How do energy consumption, output, energy price, and population growth correlate with $\mathrm{CO} 2$ emissions in Liberia?. International Journal of Global Environmental Issues, 18(3), 209-235.

Gründler, K., \& Potrafke, N. (2019). Corruption and economic growth: New empirical evidence. European Journal of Political Economy, 60, 101810.

Haggard, S., \& Tiede, L. (2011). The rule of law and economic growth: where are we?. World development, 39(5), 673-685.

Himanshu A. Amarawickrama and Lester C. Hunt, (2007), "Electricity Demand for Sri Lanka: A Time Series Analysis," Surrey Energy Economics Discussion Paper Series, No.118

Huang, C. J., \& Ho, Y. H. (2017). Governance and economic growth in Asia. The North American Journal of Economics and Finance, 39, 260-272.

IEA (2018a) World Energy Outlook 2018. IEA, Paris

IMF (2018) Data Mapper, World Economic Outlook, October 2018.

Jing, Z., Zhang, L. Y., Zhang, J. M., Shi-Huai, D., Zhang, Y. Z., Li, Y. W., ... \& Song, C. (2016). Theoretical relationship between energy consumption and economic output. Energy Sources, Part B: Economics, Planning, and Policy, 11(7), 643-650.

Johansen, S. (1988). Statistical analysis of co-integration vectors. Journal of economic dynamics and control, 12(2-3), 231-254.Omri, A., Nguyen, D. K., \& Rault, C. (2014). Causal 
interactions between $\mathrm{CO}_{2}$ emissions, FDI, and economic growth: Evidence from dynamic simultaneous-equation models. Economic Modelling, 42, 382-389.

Kao, C. (1997). Spurious Regression and Residual-Based Tests for Cointegration in Panel Data When the Cross-Section and Time-Series Dimensions are Comparable (No. 9703002). University Library of Munich, Germany.

Kim, D. H., Wu, Y. C., \& Lin, S. C. (2018). Heterogeneity in the effects of government size and governance on economic growth. Economic Modelling, 68, 205-216.

Larsson, R., Lyhagen, J., \& Löthgren, M. (2001). Likelihood-based co-integration tests in heterogeneous panels. The Econometrics Journal, 4(1), 109-142.

Lechman, E., \& Kaur, H. (2015). Economic growth and female labor force participation-verifying the U-feminization hypothesis. New evidence for 162 countries over the period 19902012. New evidence for, 162, 1990-2012.

Liu, X., Wang, Z., Sun, X., Zhang, L., \& Zhang, M. (2020). Clarifying the relationship among clean energy consumption, haze pollution and economic growth-based on the empirical analysis of China's Yangtze River Delta Region. Ecological Complexity, 44, 100871.

Maddala, G.S., and S. Wu. 1999. A comparative study of unit root tests with panel data and a new simple test. Oxford Bulletin of Economics and Statistics 61 (S1): 631-652.

Mauro, L., Pigliaru, F., \& Carmeci, G. (2018). Decentralization and growth: Do informal institutions and rule of law matter?. Journal of Policy Modeling, 40(5), 873-902. 
Montes, G. C., Bastos, J. C. A., \& de Oliveira, A. J. (2019). Fiscal transparency, government effectiveness and government spending efficiency: Some international evidence based on panel data approach. Economic Modelling, 79, 211-225.

Morozumi, A., \& Veiga, F. J. (2016). Public spending and growth: The role of government accountability. European Economic Review, 89, 148-171.

Muhammad, S., \& Long, X. (2021). Rule of law and CO2 emissions: A comparative analysis across 65 belt and road initiative (BRI) countries. Journal of Cleaner Production, 279, 123539.

Nawaz, S., Iqbal, N., \& Khan, M. A. (2014). The impact of institutional quality on economic growth: Panel evidence. The Pakistan Development Review, 15-31.

Nedić, V., Despotović, D., Cvetanović, S., Djukić, T., \& Petrović, D. (2020). Institutional reforms for economic growth in the Western Balkan countries. Journal of Policy Modeling.

Nguyen, C. P., Su, T. D., \& Nguyen, T. V. H. (2018). Institutional quality and economic growth: the case of emerging economies. Theoretical Economics Letters, 8(11), 1943.

Nirola, N., \& Sahu, S. (2019). The interactive impact of government size and quality of institutions on economic growth-evidence from the states of India. Heliyon, 5(3), e01352.

Ongo, E. N., \& Vukenkeng, A. W. (2014). Does gross capital formation matter for economic growth in the CEMAC sub-region?. EuroEconomica, 33(2).

Ouedraogo, N. S. (2013). Energy consumption and economic growth: Evidence from the economic community of West African States (ECOWAS). Energy Economics, 36, 637-647. 
Paramati, S. R., Sinha, A., \& Dogan, E. (2017). The significance of renewable energy use for economic output and environmental protection: evidence from the Next 11 developing economies. Environmental Science and Pollution Research, 24(15), 13546-13560.

Parks, B., Buntaine, M., \& Buch, B. (2017). Why developing countries get stuck with weak institutions and how foreign actors can help. The Brookings Institution, USA, Wednesday.

Qureshi, F., Qureshi, S., Vo, X. V., \& Junejo, I. (2020). Revisiting the nexus among foreign direct investment, corruption, and growth in developing and developed markets. Borsa Istanbul Review.

Radu, M. (2015). Political stability-a condition for sustainable growth in Romania?. Procedia Economics and Finance, 30, 751-757.

Rajkumar, A. S., \& Swaroop, V. (2008). Public spending and outcomes: Does governance matter?. Journal of development economics, 86(1), 96-111.

Shahbaz, M., Raghutla, C., Chittedi, K. R., Jiao, Z., \& Vo, X. V. (2020). The effect of renewable energy consumption on economic growth: Evidence from the renewable energy country attractive index. Energy, 207, 118162.

Tabassam, A. H., Hashmi, S. H., \& Rehman, F. U. (2016). Nexus between political instability and economic growth in Pakistan. Procedia-Social and Behavioral Sciences, 230, 325-334.

Tang, C. F., \& Abosedra, S. (2014). The impacts of tourism, energy consumption, and political instability on economic growth in the MENA countries. Energy Policy, 68, 458-464. 
Thanh, S. D., Hart, N., \& Canh, N. P. (2020). Public spending, public governance, and economic growth at the Vietnamese provincial level: A disaggregate analysis. Economic Systems, 100780.

Uddin, M. A., Ali, M. H., \& Masih, M. (2017). Political stability and growth: An application of dynamic GMM and quantile regression. Economic Modelling, 64, 610-625.

Ugochukwu, U. S., \& Chinyere, U. P. (2013). The impact of capital formation on the growth of Nigerian economy. Research journal of finance and accounting, 4(9), 36-42.

Wang, Q., \& Wang, L. (2020). Renewable energy consumption and economic growth in OECD countries: A nonlinear panel data analysis. Energy, 207, 118200.

Yu, S., \& Jong-A-Pin, R. (2020). Rich or alive? Political (in) stability, political leader selection, and economic growth. Journal of Comparative Economics. 


\section{Appendix: List of countries}

Country name

Mean

\begin{tabular}{|c|c|}
\hline Algeria & $1.65 \mathrm{E}+11$ \\
\hline Botswana & $1.37 \mathrm{E}+10$ \\
\hline Burkina Faso & $1.08 \mathrm{E}+10$ \\
\hline Egypt, Arab Rep. & $2.16 \mathrm{E}+11$ \\
\hline Ethiopia & $3.49 \mathrm{E}+10$ \\
\hline Kenya & $4.30 \mathrm{E}+10$ \\
\hline Libya & $5.49 \mathrm{E}+10$ \\
\hline Madagascar & $1.03 \mathrm{E}+10$ \\
\hline Malawi & $6.92 \mathrm{E}+09$ \\
\hline Mauritius & $1.03 \mathrm{E}+10$ \\
\hline Morocco & $9.52 \mathrm{E}+10$ \\
\hline Mozambique & $1.19 \mathrm{E}+10$ \\
\hline Namibia & $1.17 \mathrm{E}+10$ \\
\hline Nigeria & $3.61 \mathrm{E}+11$ \\
\hline Rwanda & $6.69 \mathrm{E}+09$ \\
\hline South Africa & $3.75 \mathrm{E}+11$ \\
\hline Sudan & $6.05 \mathrm{E}+10$ \\
\hline Tunisia & $4.27 \mathrm{E}+10$ \\
\hline Uganda & $2.75 \mathrm{E}+10$ \\
\hline Zambia & $2.04 \mathrm{E}+10$ \\
\hline Zimbabwe & $1.43 \mathrm{E}+10$ \\
\hline
\end{tabular}


Table 1: Variables description and sources

\begin{tabular}{|c|c|c|c|}
\hline Variable & Description & Sources & \\
\hline Economic output & GDP (constant 2010 US\$) & $\begin{array}{l}\text { World } \\
\text { Indicators }\end{array}$ & Development \\
\hline Energy use & Energy use (kilogram of oil equivalent per capita) & $\begin{array}{l}\text { World } \\
\text { Indicators }\end{array}$ & Development \\
\hline Capital formation & Gross fixed capital formation (constant 2020 US\$) & $\begin{array}{l}\text { World } \\
\text { Indicators }\end{array}$ & Development \\
\hline Labor force & Labor force & $\begin{array}{l}\text { World } \\
\text { Indicators }\end{array}$ & Development \\
\hline Technology & Patent application, resident & $\begin{array}{l}\text { World } \\
\text { Indicators }\end{array}$ & Development \\
\hline Control of corruption & $\begin{array}{l}\text { Measure perceptions of the extent to which public } \\
\text { power is exercised for private gain, including both } \\
\text { petty and grand forms of corruption, as well as } \\
\text { "capture" of the state by elites and private interests }\end{array}$ & $\begin{array}{l}\text { Worldwide } \\
\text { Indicators }\end{array}$ & Governance \\
\hline $\begin{array}{l}\text { Government } \\
\text { effectiveness }\end{array}$ & $\begin{array}{l}\text { Measure perceptions of the quality of public services, } \\
\text { the quality of the civil service and the degree of its } \\
\text { independence from political pressures, the quality of } \\
\text { policy formulation and implementation, and the } \\
\text { credibility of the government's commitment to such } \\
\text { policies }\end{array}$ & $\begin{array}{l}\text { Worldwide } \\
\text { Indicators }\end{array}$ & Governance \\
\hline Political stability & $\begin{array}{l}\text { Measures perceptions of the likelihood of political } \\
\text { instability and politically-motivated violence, } \\
\text { including terrorism. }\end{array}$ & $\begin{array}{l}\text { Worldwide } \\
\text { Indicators }\end{array}$ & Governance \\
\hline Regulatory quality & $\begin{array}{l}\text { Measure perceptions of the government's ability to } \\
\text { formulate and implement sound policies and } \\
\text { regulations that permit and promote private sector } \\
\text { development. }\end{array}$ & $\begin{array}{l}\text { Worldwide } \\
\text { Indicators }\end{array}$ & Governance \\
\hline Rule of laws & $\begin{array}{l}\text { Measure perceptions of the extent to which agents } \\
\text { have confidence in and abide by the rules of society, } \\
\text { and in particular the quality of contract enforcement, } \\
\text { property rights, the police, and the courts, as well as } \\
\text { the likelihood of crime and violence }\end{array}$ & $\begin{array}{l}\text { Worldwide } \\
\text { Indicators }\end{array}$ & Governance \\
\hline $\begin{array}{l}\text { Voice } \\
\text { accountability }\end{array}$ & $\begin{array}{l}\text { Measure perceptions of the extent to which a country's } \\
\text { citizens can participate in selecting their government, } \\
\text { as well as freedom of expression, freedom of } \\
\text { association, and a free media }\end{array}$ & $\begin{array}{l}\text { Worldwide } \\
\text { Indicators }\end{array}$ & Governance \\
\hline
\end{tabular}


2: Descriptive Statistics

\begin{tabular}{llllll}
\hline Variables & Obs & Mean & $\begin{array}{l}1 \\
\text { Percentile }\end{array}$ & Std. Dev. & $\begin{array}{l}99 \\
\text { Percentile }\end{array}$ \\
\hline EG & 378 & $7.580 \mathrm{e}+10$ & $4.120 \mathrm{e}+09$ & $1.120 \mathrm{e}+11$ & $4.600 \mathrm{e}+11$ \\
& & & & & \\
EU & 206 & 980.239 & 361.945 & 744.63 & 3141.438 \\
CF & 309 & $1.780 \mathrm{e}+10$ & $4.170 \mathrm{e}+08$ & $2.430 \mathrm{e}+10$ & $8.450 \mathrm{e}+10$ \\
& & & & & \\
LF & 378 & 12400000 & 544400 & 13100000 & 55288066 \\
TEC & 221 & 162.425 & 1 & 261.575 & 997 \\
\hline
\end{tabular}

Table 3: Unit root test

\begin{tabular}{ccccc}
\hline Variables & \multicolumn{2}{c}{ Levin-Lin-Chu } & \multicolumn{2}{c}{ Harris-Tzavalis } \\
\hline & Level & $1^{\text {st }}$ different & Level & $1^{\text {st }}$ different \\
\hline EO & 2.2219 & $-2.3691^{* *}$ & 0.9584 & $-0.0922^{* * *}$ \\
& $(0.9869)$ & $(0.0089)$ & $(0.9995)$ & $(0.0000)$ \\
EU & 3.2025 & $-4.9150^{* * *}$ & 0.9047 & $-0.0732^{* * *}$ \\
& $(0.9993)$ & $(0.0000)$ & $(0.9607)$ & $(0.0000)$ \\
CF & $-1.1725^{*}$ & $-3.3253^{* * *}$ & $0.7421^{* *}$ & $-0.5332^{* * *}$ \\
& $(0.1205)$ & $(0.0004)$ & $(0.0025)$ & $(0.0000)$ \\
LF & 3.9540 & $-2.3482^{* *}$ & 1.0143 & $0.4767^{* * *}$ \\
& $(1.0000)$ & $(0.0094)$ & $(1.0000)$ & $(0.0000)$ \\
TECH & $-1.5559^{*}$ & $-2.0427^{*}$ & $0.4935^{* * *}$ & $-0.3756^{* * *}$ \\
& $(0.0599)$ & $(0.0205)$ & $(0.0000)$ & $(0.0000)$ \\
\hline
\end{tabular}

Table 4: Kao test for cointegration

\begin{tabular}{lll}
\hline & Statistics & P-value \\
\hline Modified Dickey-Fuller t & 2.8921 & $0.0019^{* *}$ \\
Dickey-Fuller t & 3.2300 & $0.0006^{* * *}$ \\
Augmented Dickey-Fuller t & 3.3848 & $0.0004^{* * *}$ \\
Unadjusted modified Dickey-Fuller t & 1.2693 & $0.1022^{* *}$ \\
Unadjusted Dickey-Fuller t & 0.6160 & 0.2689 \\
\hline
\end{tabular}


Table 5: Baseline results

\begin{tabular}{|c|c|c|c|c|c|c|c|}
\hline & $(1)$ & (2) & (3) & (4) & $(5)$ & (6) & (7) \\
\hline $\mathrm{EU}$ & $\begin{array}{l}-0.00380 * * * \\
(5.02 \mathrm{e}-05)\end{array}$ & & & & & & \\
\hline $\mathrm{EU} \times \mathrm{COC}$ & & $\begin{array}{l}-0.000590 * * * \\
(2.30 \mathrm{e}-05)\end{array}$ & & & & & \\
\hline EU x GE & & & $\begin{array}{l}-0.000650 * * * \\
(2.75 \mathrm{e}-05)\end{array}$ & & & & \\
\hline EU x PS & & & & $\begin{array}{l}0.000493 * * * \\
(1.37 \mathrm{e}-05)\end{array}$ & & & \\
\hline EU x RQ & & & & & $\begin{array}{l}0.000128 * * * \\
(1.63 \mathrm{e}-05)\end{array}$ & & \\
\hline EU x RL & & & & & & $\begin{array}{l}0.000924 * * * \\
(2.77 \mathrm{e}-05)\end{array}$ & \\
\hline EU x VA & & & & & & & $\begin{array}{l}0.000238 * * * \\
(1.71 \mathrm{e}-05)\end{array}$ \\
\hline $\mathrm{CF}$ & $\begin{array}{l}-0.120 * * * \\
(0.0201)\end{array}$ & $\begin{array}{l}-0.201 * * * \\
(0.0195)\end{array}$ & $\begin{array}{l}-0.251 * * * \\
(0.0195)\end{array}$ & $\begin{array}{l}-0.466 * * * \\
(0.0179)\end{array}$ & $\begin{array}{l}-0.162 * * * \\
(0.0187)\end{array}$ & $\begin{array}{l}-0.194 * * * \\
(0.0173)\end{array}$ & $\begin{array}{l}-0.394 * * * \\
(0.0177)\end{array}$ \\
\hline LF & $\begin{array}{l}2.585 * * * \\
(0.103)\end{array}$ & $\begin{array}{l}1.858 * * * \\
(0.0992)\end{array}$ & $\begin{array}{l}1.891 * * * \\
(0.0977)\end{array}$ & $\begin{array}{l}2.449 * * * \\
(0.0908)\end{array}$ & $\begin{array}{l}1.245 * * * \\
(0.0956)\end{array}$ & $\begin{array}{l}2.038 * * * \\
(0.0895)\end{array}$ & $\begin{array}{l}2.044 * * * \\
(0.0896)\end{array}$ \\
\hline TEC & $\begin{array}{l}-0.000515^{* * *} \\
(4.37 \mathrm{e}-05)\end{array}$ & $\begin{array}{l}0.00108 * * * \\
(5.44 \mathrm{e}-05)\end{array}$ & $\begin{array}{l}0.000495 * * * \\
(4.31 \mathrm{e}-05)\end{array}$ & $\begin{array}{l}-0.000132 * * * \\
(4.02 \mathrm{e}-05)\end{array}$ & $\begin{array}{l}-2.41 \mathrm{e}-05 \\
(4.19 \mathrm{e}-05)\end{array}$ & $\begin{array}{l}-8.79 \mathrm{e}-05 * * \\
(3.77 \mathrm{e}-05)\end{array}$ & $\begin{array}{l}-0.000319 * * * \\
(3.81 \mathrm{e}-05)\end{array}$ \\
\hline Year-fixed effects & Yes & Yes & Yes & Yes & Yes & Yes & Yes \\
\hline Constant & $\begin{array}{l}-9.134 * * * \\
(1.581)\end{array}$ & $\begin{array}{l}0.329 \\
(1.549)\end{array}$ & $\begin{array}{l}0.968 \\
(1.521)\end{array}$ & $\begin{array}{l}-1.957 \\
(1.385)\end{array}$ & $\begin{array}{l}9.582 * * * \\
(1.472)\end{array}$ & $\begin{array}{l}-1.783 \\
(1.367)\end{array}$ & $\begin{array}{l}2.499 * \\
(1.375)\end{array}$ \\
\hline Observations & 104 & 104 & 104 & 104 & 104 & 104 & 104 \\
\hline R-squared & 0.858 & 0.886 & 0.818 & 0.848 & 0.957 & 0.915 & 0.819 \\
\hline
\end{tabular}

Standard errors in parentheses

$* * * \mathrm{p}<0.01, * * \mathrm{p}<0.05, * \mathrm{p}<0.1$ 
Table 6: FMOLS with additional control variables

\begin{tabular}{|c|c|c|c|c|c|c|c|}
\hline & (1) & (2) & (3) & (4) & (5) & (6) & (7) \\
\hline EU & $\begin{array}{l}-0.00506 * * * \\
(5.02 \mathrm{e}-05)\end{array}$ & & & & & & \\
\hline EU x COC & & $\begin{array}{l}-0.000791 * * * \\
(2.30 \mathrm{e}-05)\end{array}$ & & & & & \\
\hline EU x GE & & & $\begin{array}{l}-0.000585^{* * * *} \\
(2.75 \mathrm{e}-05)\end{array}$ & & & & \\
\hline EU x PS & & & & $\begin{array}{l}0.000573 * * * \\
(1.37 \mathrm{e}-05)\end{array}$ & & & \\
\hline EU x RQ & & & & & $\begin{array}{l}0.000227 * * * \\
(1.63 \mathrm{e}-05)\end{array}$ & & \\
\hline EU x RL & & & & & & $\begin{array}{l}0.00125 * * * \\
(2.77 \mathrm{e}-05)\end{array}$ & \\
\hline EU x VA & & & & & & & $\begin{array}{l}0.000216 * * * \\
(1.71 \mathrm{e}-05)\end{array}$ \\
\hline $\mathrm{CF}$ & $\begin{array}{l}-0.194 * * * \\
(0.0201)\end{array}$ & $\begin{array}{l}-0.304 * * * \\
(0.0195)\end{array}$ & $\begin{array}{l}-0.406 * * * \\
(0.0195)\end{array}$ & $\begin{array}{l}-0.596 * * * \\
(0.0179)\end{array}$ & $\begin{array}{l}-0.255^{* * *} \\
(0.0187)\end{array}$ & $\begin{array}{l}-0.289 * * * \\
(0.0173)\end{array}$ & $\begin{array}{l}-0.514 * * * \\
(0.0177)\end{array}$ \\
\hline $\mathrm{LF}$ & $\begin{array}{l}3.139 * * * \\
(0.103)\end{array}$ & $\begin{array}{l}2.129 * * * \\
(0.0992)\end{array}$ & $\begin{array}{l}1.954 * * * \\
(0.0977)\end{array}$ & $\begin{array}{l}2.562 * * * \\
(0.0908)\end{array}$ & $\begin{array}{l}1.386 * * * \\
(0.0956)\end{array}$ & $\begin{array}{l}2.412 * * * \\
(0.0895)\end{array}$ & $\begin{array}{l}2.087 * * * \\
(0.0896)\end{array}$ \\
\hline TEC & $\begin{array}{l}-0.000596 * * * \\
(4.37 \mathrm{e}-05)\end{array}$ & $\begin{array}{l}0.00158 * * * \\
(5.44 \mathrm{e}-05)\end{array}$ & $\begin{array}{l}0.000610 * * * \\
(4.31 \mathrm{e}-05)\end{array}$ & $\begin{array}{l}7.46 \mathrm{e}-05^{*} \\
(4.02 \mathrm{e}-05)\end{array}$ & $\begin{array}{l}-8.65 \mathrm{e}-05 * * \\
(4.19 \mathrm{e}-05)\end{array}$ & $\begin{array}{l}-3.05 e-05 \\
(3.77 e-05)\end{array}$ & $\begin{array}{l}-0.000154 * * * \\
(3.81 \mathrm{e}-05)\end{array}$ \\
\hline PD & $\begin{array}{l}-0.0125 \\
(0.0548)\end{array}$ & $\begin{array}{l}1.126 * * * \\
(0.0609)\end{array}$ & $\begin{array}{l}0.902 * * * \\
(0.0576)\end{array}$ & $\begin{array}{l}0.0668 \\
(0.0490)\end{array}$ & $\begin{array}{l}-0.220 * * * \\
(0.0536)\end{array}$ & $\begin{array}{l}0.344 * * * \\
(0.0472)\end{array}$ & $\begin{array}{l}0.431 * * * \\
(0.0479)\end{array}$ \\
\hline IC & $\begin{array}{l}0.577 * * * \\
(0.00716)\end{array}$ & $\begin{array}{l}-0.0612^{* * * *} \\
(0.00428)\end{array}$ & $\begin{array}{l}0.00440 \\
(0.00432)\end{array}$ & $\begin{array}{l}0.0209 * * * \\
(0.00386)\end{array}$ & $\begin{array}{l}0.00523 \\
(0.00400)\end{array}$ & $\begin{array}{l}-0.0683 * * * \\
(0.00407)\end{array}$ & $\begin{array}{l}-0.0203 * * * \\
(0.00413)\end{array}$ \\
\hline $\mathrm{MF}$ & $\begin{array}{l}-0.391 * * * \\
(0.0519)\end{array}$ & $\begin{array}{l}1.266^{* * * *} \\
(0.0585)\end{array}$ & $\begin{array}{l}1.013 * * * \\
(0.0542)\end{array}$ & $\begin{array}{l}0.123 * * * \\
(0.0460)\end{array}$ & $\begin{array}{l}-0.150 * * * \\
(0.0507)\end{array}$ & $\begin{array}{l}0.460 * * * \\
(0.0444)\end{array}$ & $\begin{array}{l}0.541 * * * \\
(0.0451)\end{array}$ \\
\hline UA & $\begin{array}{l}-0.0249 \\
(0.0770)\end{array}$ & $\begin{array}{l}-1.661 * * * \\
(0.0860)\end{array}$ & $\begin{array}{l}-1.356 * * * \\
(0.0813)\end{array}$ & $\begin{array}{l}-0.121^{*} \\
(0.0690)\end{array}$ & $\begin{array}{l}0.289 * * * \\
(0.0756)\end{array}$ & $\begin{array}{l}-0.514 * * * \\
(0.0664)\end{array}$ & $\begin{array}{l}-0.660 * * * \\
(0.0674)\end{array}$ \\
\hline LO & $\begin{array}{l}-0.150 * * * \\
(0.0141)\end{array}$ & $\begin{array}{l}0.327 * * * \\
(0.0154)\end{array}$ & $\begin{array}{l}0.244 * * * \\
(0.0140)\end{array}$ & $\begin{array}{l}0.0540 * * * \\
(0.0124)\end{array}$ & $\begin{array}{l}-0.0255^{*} \\
(0.0134)\end{array}$ & $\begin{array}{l}0.153 * * * \\
(0.0120)\end{array}$ & $\begin{array}{l}0.152 * * * \\
(0.0122)\end{array}$ \\
\hline IR & $0.0951 * *$ & $-0.970 * * *$ & $-0.781 * * *$ & $-0.121 * * *$ & $0.120 * * *$ & $-0.355 * * *$ & $-0.418 * * *$ \\
\hline
\end{tabular}




\begin{tabular}{|c|c|c|c|c|c|c|c|}
\hline & $(0.0430)$ & $(0.0480)$ & $(0.0450)$ & $(0.0384)$ & $(0.0420)$ & $(0.0370)$ & $(0.0377)$ \\
\hline Year-fixed effects & Yes & Yes & Yes & Yes & Yes & Yes & Yes \\
\hline \multirow{2}{*}{ Linear } & $-0.0127 * * *$ & $-0.0887 * * *$ & $-0.0789 * * *$ & $-0.0232 * * *$ & -0.00299 & $-0.0382 * * *$ & $-0.0470 * * *$ \\
\hline & $(0.00267)$ & $(0.00313)$ & $(0.00293)$ & $(0.00238)$ & $(0.00267)$ & $(0.00230)$ & $(0.00234)$ \\
\hline \multirow[t]{2}{*}{ Constant } & $-17.89 * * *$ & $4.935 * * *$ & $9.447 * * *$ & -0.0573 & $8.849 * * *$ & $-3.134 * * *$ & $7.580 * * *$ \\
\hline & $(1.399)$ & $(1.333)$ & $(1.318)$ & $(1.218)$ & $(1.284)$ & $(1.203)$ & $(1.207)$ \\
\hline Observations & 104 & 104 & 104 & 104 & 104 & 104 & 104 \\
\hline R-squared & 0.765 & 0.817 & 0.728 & 0.789 & 0.931 & 0.868 & 0.752 \\
\hline
\end{tabular}

Standard errors in parentheses

$* * * \mathrm{p}<0.01, * * \mathrm{p}<0.05, * \mathrm{p}<0.1$ 
Fig 1: Theoretical background

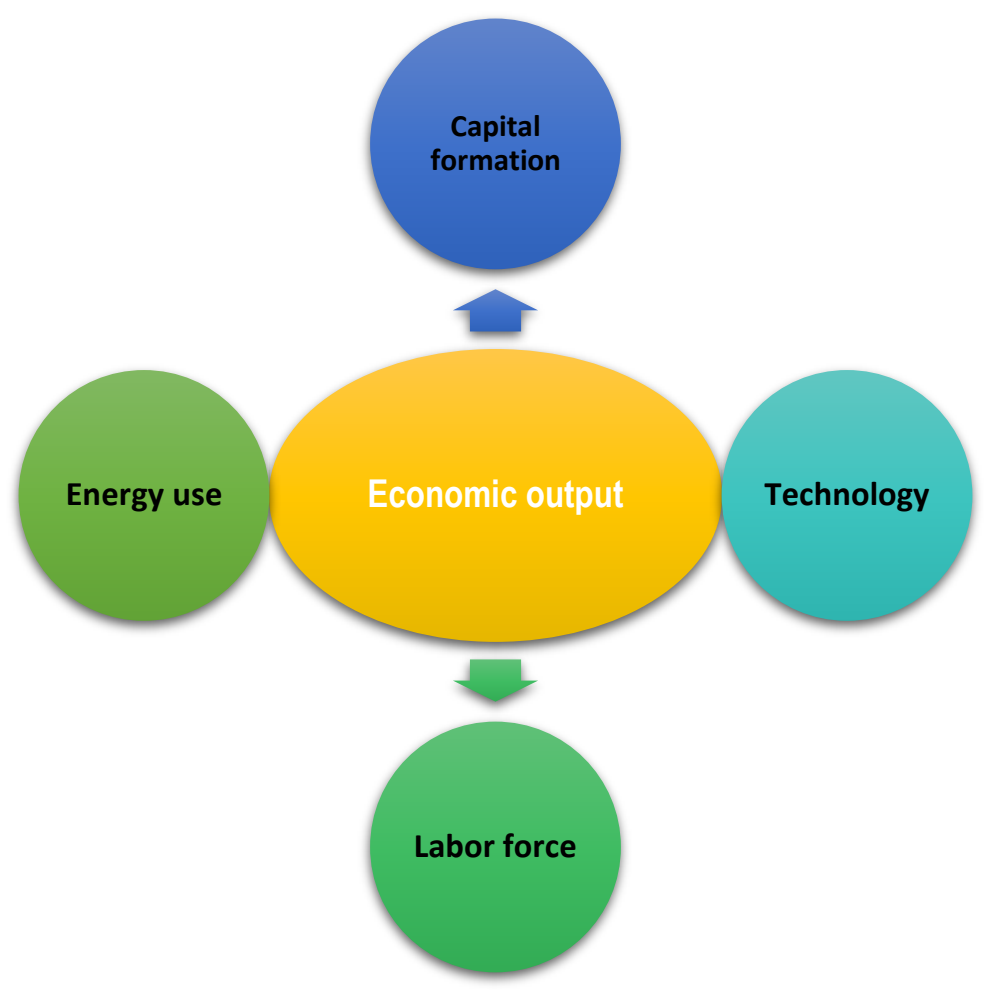


Fig 2: Descriptive statistics
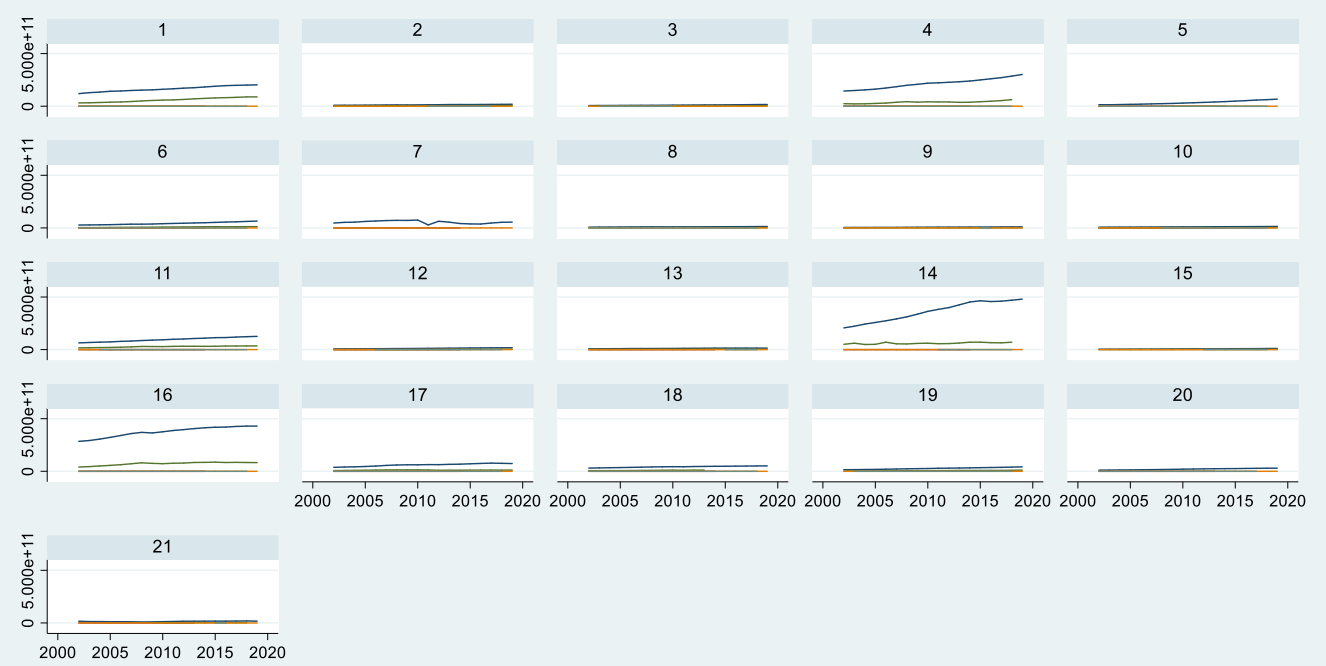

$2000 \quad 200520102015202020002005201020152020200020052010 \quad 201520202000 \quad 200520102015 \quad 2020$

20002005201020152020

Time

\begin{tabular}{ll}
\hline Economic output & Energy use \\
Capita formation & Labor force \\
Technology & \\
\hline
\end{tabular}

Graphs by group(CountryName) 